\title{
Lectures in lockdown: trying to rescue the lecture as event
}

\section{Paul O'Kane}

Central Saint Martins College, University of the Arts London, UK

Keywords: Covid-19; lectures; lockdown; live; recorded; sage.

\section{The challenge}

... anxiety concerns the physical presence of the lecturer in front of his or her students: their gestures, movements, facial expressions, and eye contact. Students using recordings will miss much of this, while lecturers may need to inhibit action to accommodate fixed cameras. (Crook, 2015).

Come the 2020 lockdown, and teaching online, the opportunity to stride about, sage-like (King, 1993) in front of students, extending my research, here, now, 'live', was severely curtailed - neutered in fact. My colleagues and I discussed how to continue delivering our Fine Art Critical Studies lectures. A majority decided to pre-record them, giving students a chance to view in their own time before attending a staffed, online Q\&A. I was never quite satisfied with this decision, fearing it would cramp our style and thus stifle students' enthusiasm (a concern previously illuminated in an article by Brack and Cowling titled 'How digital natives are killing the sage on stage' (2015)).

Watching first attempts at pre-recorded lectures I was impressed by the well-organised materials suitably paced for students to digest, but nervous about the deadpan delivery we tended to make to a passively waiting camera. I feared that, lacking the real audience and live lecture we tended to sound more wooden and didactic. So, how could I try to rescue the event-ful qualities of the live lecture while embracing the generous new resource provided by the pre-recorded lecture? 


\section{The response}

... to enthuse and inspire students through their liveness and the physical

presence of the lecturer in real time and space. (French and Kennedy, 2017, p.647)

When my turn came to supply a lecture, I accessed strategies accumulated while working as a writer, lecturer, artist, and musician, plus as a reader of Gilles Deleuze's philosophy of event (1993) and Joe Moran's First you write a sentence (2019). I decided to deliver only the first draft of my lecture, written, as usual, in fountain pen on paper, a live event in itself, while more aware than usual that the live-ness of this event had to be retained. I allowed a greater degree of self-reflexivity than usual into the writing, knowing this makes it more 'live' and implicitly requires the audience to also be 'present', engaging in a way more akin to theatre, performed music, or poetry reading.

Next, I prepared myself to video-record only the first reading of my first written draft, again welcoming the self-imposed pressure of denying myself any remaking. ${ }^{1}$ This might all sound solipsistic but I believe it concurs with what French and Kennedy mean when they say 'engaging lecturers do not merely present factual information; they develop a narrative around the subject matter' (2017, p.647), only here 'narrative' and 'subject matter' became fused by self-reflexivity.

\section{Recommendations}

Penson argues that lectures need to be reconceived as 'a learning event' (Penson, 2012, cited French and Kennedy, 2017, p.645).

This was not the first time I had written or lectured in an event-ful and self-reflexive way, but it was the first time l'd had a clear reason to do so and made what I was doing so clear to myself and my audience. I took risks and publicly invited - via the Q\&A - immediate critical responses. I had some good feedback. One student said it was 'very poetic' which led me to believe that they had, probably for the first time, considered the 'weight', value, particularity, and provenance of the words used in a lecture. Meanwhile, a colleague told

\footnotetext{
1 See Biesenbach, London and Eamon, Video Acts (2002), a millennial curation of early home video use by studio artists.
} 
me it was 'a work of art', echoing Richard Gunderman who describes a great lecture as a work of art, and 'a kind of dance, in which lecturer and listeners watch, respond to, and draw energy and inspiration from each other' (Gunderman, 2013).

Such praise suggests that, rather than allow online, pre-recorded lecturing to become more wooden and less 'live', we might use this opportunity to shift recorded lectures into a more spontaneous, productive, and valuable mode. I would therefore advise lecturers to think both of their recording and the drafting of their text as event-ful and event-ual. This self-imposed pressure should make recording more exciting for audience and lecturer alike. $^{2}$

There is much talk in our students' world that is lively but of little value, and so, if we are privileged to lecture, we should uphold and adapt the special value of the lecturer, prove the value of our presence, mark the event, and share the worth of every word as well as respecting the value of the time and attention of our audience. I would thus advise those whose recorded lectures might seem 'wooden', to look into aspects of our lives and practices that involve some performative element, and draw across, into our lecturing, any lessons and skills regarding performance and events that might have been learned while, for instance, acting, poetry-reading, drawing, playing a musical instrument, or even participating in a sport.

The recorded, online lecture need not be diametrically opposed to, nor a compromised version of, the real live lecture. Rather, we might cultivate an innovative middle ground by recording online lectures that are as event-ful or event-ual as we can make them, and that regard their writing, their recording, and their viewing as live events. If so, we might be able to reinterpret and thereby concur with Jonathan Wolff's claim that:

For as long as the lecture is regarded as better than internet-based learning, it will survive on a substantial scale. And wherein lies its superiority? . . . It is live. It is real. It is put on with you in mind, even if you are one of a large crowd. . . Somehow live learning can be open and transformative in a way that transcends its educational function. Maybe one day we'll work out how to do this better some other way. For the moment, while internet technology, if used well, can certainly enhance university

\footnotetext{
2 There may in fact be a parallel conversation within writings that discuss theories of music recording, which can notoriously misrepresent and knock the life out of music that works wonderfully on stage.
} 
teaching, and provide smooth access to excellent education for those unable to attend university, it is too early to write the lecture's obituary. (Wolff, 2013).

\section{References}

Biesenbach, K., London B. and Eamon, C. (2002) Video acts: single channel works from the collections of Pamela and Richard Kramlich and New Art Trust. Long Island City, N.Y.: P.S.1 Contemporary Art Center.

Brack, C. and Cowling, M. (2015) 'How digital natives are killing the sage on stage', The Conversation, 6 May. Available at: https://theconversation.com/how-digital-nativesare-killing-the-sage-on-the-stage-39923 (Accessed: 13 August 2021).

Crook, C. (2015) 'Should all university lectures be automatically recorded?', The Conversation, 8 April. Available at: https://theconversation.com/should-alluniversity-lectures-be-automatically-recorded-39158, (Accessed: 14 August 2021).

Deleuze, G. (1993) The Fold, Leibniz and the Baroque. London: The Athlone Press.

French, S. and Kennedy, G. (2017) 'Reassessing the value of university lectures' Teaching In Higher Education, 22(6), pp.639-654. https://doi.org/10.1080/13562517.2016.1273213.

Gunderman, R. (2013) 'Is the lecture dead?', The Atlantic, January 29. Available at: http://www.theatlantic.com/health/archive/2013/01/is-the-lecture-dead/272578/ (Accessed: 26 November 2015).

King, A. (1993) 'From sage on the stage to guide on the side', College Teaching, 41(1), pp.30-35. Available at: https://www.jstor.org/stable/27558571 ?origin=JSTOR-pdf (Accessed: 26 June 2021).

Moran, J. (2019) First you write a sentence. London: Penguin. 
Penson, P. E. (2012) 'Lecturing: a lost art', Currents in Pharmacy Teaching and Learning 4(1), pp.72-76.

Wolff, J. (2013) 'It's too early to write off the lecture', The Guardian, 24 June. Available at: https://www.theguardian.com/education/2013/jun/24/university-lecture-still-bestlearning (Accessed: 13 August 2021).

\section{Author details}

Paul O'Kane is an artist and writer, lecturing on art and culture at Central Saint Martins College. Paul is a founding member of eeodo artists' publishers and a long-standing member of AICA (International Association of Art Critics). He has published a series of artists' books, and numerous articles, essays, and reviews for leading journals and magazines, including Third Text and Art Monthly. Paul's research, writing, and lecturing is rooted in Fine Art but always informed by a broader cultural field and a historical model. Paul is currently preparing a book on history in contemporary art for Routledge. 